\title{
DE
} DE GRUYTER OPEN

Arch. Min. Sci., Vol. 61 (2016), No 2, p. 443-456

Electronic version (in color) of this paper is available: http://mining.archives.pl

DOI 10.1515/amsc-2016-0032

NIKODEM SZLAZZAK*, MAREK KORZEC*

\section{METHOD FOR DETERMINING THE COALBED METHANE CONTENT WITH DETERMINATION THE UNCERTAINTY OF MEASUREMENTS}

\author{
METODA WYZNACZANIA ZAWARTOŚCI METANU W POKLADACH WĘGLA \\ $Z$ OKREŚLENIEM NIEPEWNOŚCI POMIAROWEJ
}

Methane has a bad influence on safety in underground mines as it is emitted to the air during mining works. Appropriate identification of methane hazard is essential to determining methane hazard prevention methods, ventilation systems and methane drainage systems. Methane hazard is identified while roadways are driven and boreholes are drilled. Coalbed methane content is one of the parameters which is used to assess this threat. This is a requirement according to the Decree of the Minister of Economy dated 28 June 2002 on work safety and hygiene, operation and special firefighting protection in underground mines. For this purpose a new method for determining coalbed methane content in underground coal mines has been developed. This method consists of two stages - collecting samples in a mine and testing the sample in the laboratory. The stage of determining methane content in a coal sample in a laboratory is essential. This article presents the estimation of measurement uncertainty of determining methane content in a coal sample according to this methodology.

Keywords: coalbed methane content, method for determining the coalbed methane content, methane hazard, uncertainty of measurement

Odpowiednie rozpoznanie zagrożenia metanowego w kopalniach węgla kamiennego ma istotne znaczenie dla doboru profilaktyki jego zwalczania. Rozpoznanie to jest prowadzone na etapie drążenia wyrobisk i wykonywania wierceń rozpoznawczych. Jednym z parametrów węgla służących do oceny stanu zagrożenia metanowego jest metanonośność, której oznaczanie, zgodnie z Rozporządzeniem Ministra Gospodarki w sprawie bezpieczeństwa i higieny pracy, prowadzenia ruchu oraz specjalistycznego zabezpieczenia przeciwpożarowego w podziemnych zakładach górniczych, jest obligatoryjne w polskich kopaniach węgla kamiennego. Metanonośność jest parametrem wykorzystywanym w prognozach metanowości, które służą do oceny stanu zagrożenia metanowego i pozwalają ustalić profilaktykę oraz sposoby jego zwalczania. Jest również parametrem decydującym o zaliczeniu pokładu lub jego części do jednej z kategorii zagrożenia metanowego oraz jest uwzględniana przy zaliczaniu pokładów do kategorii skłonnych do wyrzutów gazów i skał.

* AGH UNIVERSITY OF SCIENCE AND TECHNOLOGY, FACULTY OF MINING AND GEOENGINEERING, AL. A. MICKIEWICZA 30, 30-059 KRAKOW, POLAND. E-mail: szlazak@agh.edu.pl, mkorzec@agh.edu.pl 
W związku z tym istotne jest prowadzenie oznaczeń metanonośności zgodnie z ustaloną metodyką badawczą, która pozwoli na uzyskiwanie wystarczająco dokładnych wyników, a wyniki oznaczeń będą uzyskiwane stosunkowo szybko.

Dla celów oznaczania metanonośności opracowana została nowa metoda oznaczania metanonośności. W artykule przedstawiona została charakterystyka opracowanej metody, jak również opisany został sposób obliczania wyniku końcowego oznaczenia. W celu wyznaczenia zawartości metanu w próbce węgla należy wykonać obliczenia zgodnie z zależnościami (4.1-4.10). Zgodnie z opracowaną metodą wynik końcowy oznaczenia metanonośności stanowi określona w laboratorium zawartość metanu w próbce węgla powiększona o wyznaczony doświadczalnie współczynnik przeliczeniowy, który uwzględnia stratę gazu związaną z poborem próbki węgla do badań w warunkach kopalnianych wg wzoru (4.11). Wyznaczenie straty gazu związanej z poborem próbki węgla do badań zostało określone w oparciu o badania sorpcji i desorpcji metanu z próbek węglowych. Dla opracowanej metody straty gazu zostały przyjęte na poziomie $12 \%$.

Z punktu widzenia wyznaczenia metanonośności ważnym etapem jest określenie zawartości metanu w pobranej do badań próbce węgla. W tym celu uwzględniane jest 13 parametrów, które mierzone są w czasie poboru próbki do badań oraz w czasie jej późniejszego badania w laboratorium. Parametry te, wraz z błędami związanymi z ich pomiarem, zostały zestawione w tabeli 1. Zależność pozwalającą na wyznaczenie zawartości metanu w próbce węgla, uwzględniającą wszystkie parametry potrzebne do jej wyznaczenia, można zapisać w postaci równania (6.1). Z uwagi na przyjęcie wyznaczonego doświadczalnie współczynnika uwzględniającego stratę gazu związaną poborem próbki węgla do badań w artykule przeprowadzona została analiza niepewności pomiarowej związanej z wyznaczaniem zawartości metanu w próbce węgla w laboratorium. Obliczenia niepewności zostały wykonane dla niepewności standardowej oraz niepewności maksymalnej. W tym celu wyznaczono pochodne cząstkowe zawartości metanu w próbce węgla względem poszczególnych parametrów wchodzących w skład zależności (6.1). Pochodne te zestawiono w tabeli 2.

Otrzymane dla przeprowadzonych oznaczeń wyniki pozwalają stwierdzić, że dla przeanalizowanych próbek węgla względna niepewność standardowa wyznaczenia zawartości metanu w próbce węgla nie przekroczyła 2,5\%, natomiast względna niepewność maksymalna nie przekroczyła 7,0\%. Przedstawione na rysunkach 4 i 5 wykresy pozwalają stwierdzić, że większą niepewnością względną charakteryzują się oznaczenia metanonośności wykonywane dla niższych zawartości metanu w węglu.

Przeprowadzona analiza objęła również wyznaczenie udziałów błędów popełnianych przy wyznaczaniu poszczególnych parametrów mających wpływ na ostateczny wynik oznaczenia zawartości metanu w próbce węgla. Analiza średnich udziałów tych błędów w niepewności wyznaczenia zawartości metanu w próbce świadczy o tym, że na wynik oznaczenia największy wpływ ma dokładność oznaczenia takich parametrów jak: stężenie metanu w mieszaninie z odgazowania, masa próbki węgla, ciśnienie w zbiorniku pomiarowym, objętość zbiornika pomiarowego, zawartość popiołu oraz stężenie metanu w wyrobisku w momencie poboru próbki do badań. Udziały błędów pomiarowych poszczególnych parametrów w niepewności wyznaczenia zawartości metanu w próbce węgla zostały przedstawione w tabeli 3. Dokładność wyznaczenia pozostałych parametrów jest wystarczająco duża i nie wpływa w sposób istotny na wynik oznaczenia.

Słowa kluczowe: metanonośność, metoda oznaczania metanonośności, zagrożenie metanowe, niepewność pomiaru

\section{Introduction}

Methane hazard is one of the most dangerous threats in Polish coal mines. Methane present in coal seams has a bad influence on safety in underground mines as it is emitted during mining works (Branny, 2006; Szlązak \& Kubaczka, 2012). There are some parameters which are used to describe the level of methane hazard. One of the parametres used to describe the level of methane hazard is coalbed methane content. It is defined as the volume of natural methane included in a Megagram of clear carbon substance ( $\mathrm{Mg} \mathrm{ccs}$ ). The knowledge about its deployment in coal seams is very important to ensure the safety in underground mines. The Amount of methane obtained from the forecast of gas emission allows to determine the methane hazard prevention, ventilation system and methane drainage. 
According to the Decree of the Minister of Economy dated 28 June 2002 on work safety and hygiene, operation and special firefighting protection in underground mines, measurements of coalbed methane content should be conducted in:

- test boreholes drilled to assess the properties of coal seams,

- shafts (blind shafts) and driven roadways while crossing coal seams whose thickness exceeds $0.4 \mathrm{~m}$,

- roadways driven in coal seams.

Approximately 1600 to 2000 measurements of coalbed methane content are conducted in Polish coal mines every year (Korzec, 2013). For this reason, it is a matter of utmost importance that all the measurements adhere to an established methodology. This methodology should allow us to obtain sufficient accuracy of measurements (i.e. results accurate enough for this purpose) within a relatively short time.

Determining coalbed methane content can be carried out in accordance with the Polish Standard PN-G-44200. This standard has been elaborated on the basis of studies conducted during the last few years at the AGH University of Science and Technology in Cracow by the research team by directed professor Szlazak. The research has resulted in developing a methodology for determining methane content in coalbeds (NCBiR 2009-2010; Szlązak et al., 2011; Korzec, 2013).

The process of determining methane content in coalbeds consists basically of two stages. The first stage involves collecting coal samples in a mine and closing them in airtight steel containers. The second stage consists in measuring coal methane content in a laboratory. Methane content in a coal sample is enhanced by an experimentally obtained loss of gas and is the result of the determined coalbed methane content.

Because there is no possibility of estimating measurement uncertainty while collecting samples of coal in a mine, attention is focused entirely on the methodology of testing samples in a laboratory. For this procedure, an analysis of measurement uncertainty in determining methane content in a coal sample has been conducted.

Estimating measurement uncertainty is an inherent procedure in developing any measurement methodology (Terenowski, 2010) because error-free measurements are impossible. If we conduct measurements, we must be prepared to accept inevitable inaccuracies. Measurement errors happen at each stage of the process. There are many sources of measurement uncertainty and there is a considerable amount of literature on the subject (Arendarski, 2006; Giercuszkiewicz-Bajtlik \& Gworek, 2009; Taylor, 1999; Terenowski, 2010).

Knowledge of measurement uncertainty is very important both for the company which conducts measurements and for the company which later uses their results. Giving measurement results along with the estimated measurement uncertainty proves its credibility and enables comparing them with the results obtained by using different measurement methods or conducted by other companies.

There are a lot of factors which have an influence on measurement uncertainty. The most important are the following:

- research methodology used,

- measurement devices used,

- skills and experience of the person who conducts measurements.

Methods of measuring physical and chemical parametres can be divided into two categories: direct and indirect. A direct measurement takes place when the result is obtained directly in the 
form of a reading provided by a measuring device; in this case, the obtained value is compared to a benchmark. In indirect measurements, the value is determined on the basis of direct measurements of different physical or chemical properties that can be related to a well-known physical or chemical law.

\section{New method for determining the coalbed methane content}

A new method of determining methane content in coalbeds has been developed on the basis of studies (NCBiR 2009-2010). The method provides a framework of procedures for both coal sampling in a mine and laboratory tests to which the samples are later subjected. As a result, uniformity is imposed on the procedures for determining methane content in coalbeds. The method makes it possible to determine methane content on the basis of a collected sample in the form of drillings.

In principle, the method consists in degasifying coal samples and measuring the volume of methane released from the samples to determine the methane content in a given coalbed.

In order to determine the methane content of a coalbed, it is necessary to collect two samples of coal in the mine. The samples are drillings left after drilling boreholes into a coal layer. The length of boreholes should not exceed 4 metres and the distance between them should not be greater than 1 metre. After sifting the drillings, they are divided into two portions. The amount of ca. 100 cubic $\mathrm{cm}$ of drillings exceeding $1.0 \mathrm{~mm}$ in diameter is put in an airtight container. Another portion of ca. 5 cubic $\mathrm{cm}$ of drillings with a diameter of $0.5-1.0 \mathrm{~mm}$ is placed in a manometric desorbometer in order to determine the desorption intensity indicator. The entire procedure from the moment of drilling a borehole at the depth of 3.5-4.0 metres until the samples are sealed in the airtight container and in the desorbometer should not last longer than 120 seconds. Next, the approximate methane content in the coalbed is to be calculated on the basis of the desorption intensity indicator. At the same time, simultaneous measurements of methane concentration and atmospheric pressure in the place of sampling are conducted.

Subsequent procedures connected with determining methane content take place in a laboratory, where two sealed airtight steel containers with coal samples are transported. The testing procedure in the laboratory leads to the determination of methane content in the sample. In the next step, the obtained result is used to calculate the methane content in the coalbed while taking into account the methane loss during sampling in the conditions of the mine.

The description of the method involves a precise description of all steps that have to be taken in order to determine methane content, as well as of tools and the technical apparatus needed for this purpose.

In order to facilitate the procedure, special forms were provided for recording the results. A separate form is used by the person collecting a sample in the mine, whereas a different type is filled by the laboratory researchers.

In addition, the method includes diagrammes and tables that enable determining the approximate value of methane content on the basis of the desorption intensity indicator. The relationship between approximate methane content and the desorption intensity indicator is explained in literature (Szlązak et al., 2011; Korzec, 2013). 


\section{Loss of methane connected with collecting coal samples for measurements}

The gas loss occurring during sampling coal underground was figured out by testing the sorption of methane on coal and its desorption from coal. The tests were carried out using an IGA-001 gas sorption analyzer on coal samples prepared specifically for this purpose (Szlązak et al., 2011; Korzec, 2013). An example of a sorption and adsorption curve calculated by the IGA-001 analyzer is presented in Figure 1. The tests were conducted for three values of saturation pressure: $0.5,1.0$ and 1.5 MPa. The tested coal samples were saturated with methane for 1 hour. The literature on the subject (Wierzbicki, 2013) contains descriptions of tests in which coal samples were subjected to saturation with methane for more than 1 hour, depending on the diffusion coefficient of carbon.

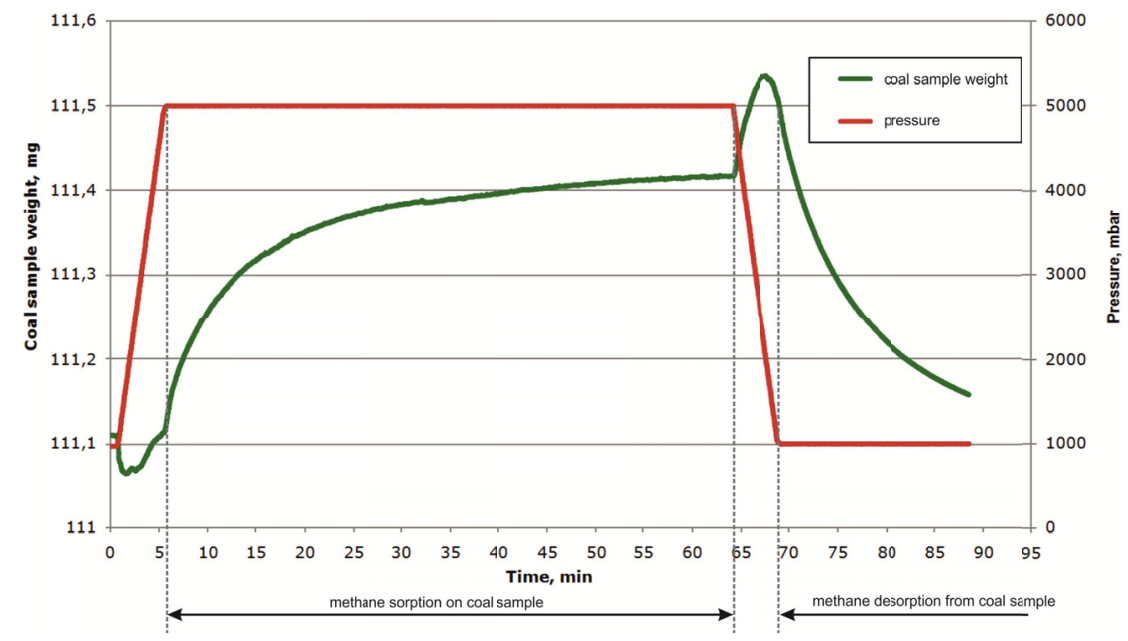

Fig. 1. Process of methane sorption on coal samples and desorption from coal samples for the saturation pressure of $0.5 \mathrm{MPa}$

Selected sections of the obtained curves, illustrating the process of the sorption of methane on coal, were approximated by a Langmuir equation. In order to approximate the curves the following equation was applied:

$$
M(\tau)=M_{o}-\left(a \cdot\left(\tau^{n}\right)\right), \mathrm{m}^{3} \mathrm{CH}_{4} / \mathrm{Mg} \operatorname{ccs}
$$

where:

$M_{o}$ — initial methane content (at the onset of desorption) in $\mathrm{m}^{3} \mathrm{CH}_{4} / \mathrm{Mg}$ ccs,

$\tau$ - time that elapsed from the onset of desorption of methane from the coal sample in $\min$,

$a, n$ - coefficients depending on the properties of coal and of the desorption process.

Examples of approximations are presented in Figures 2 and 3. 


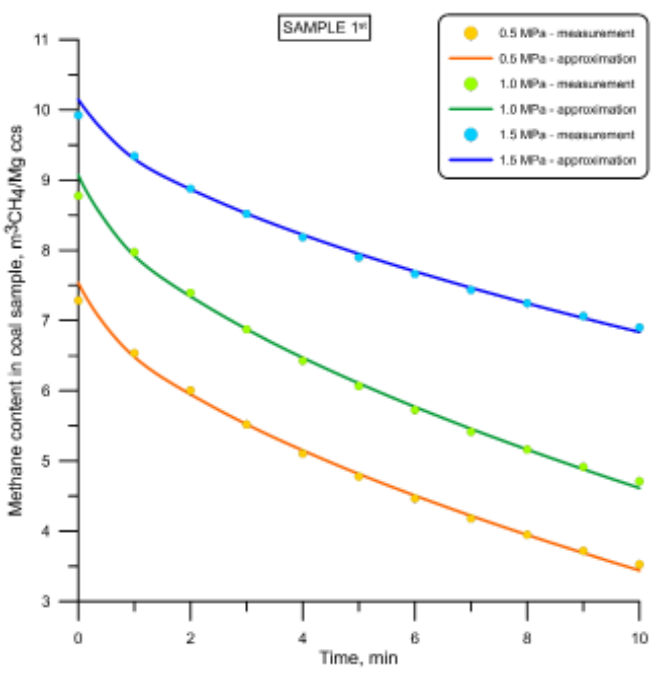

Fig. 2. Desorption curves (sample 1)

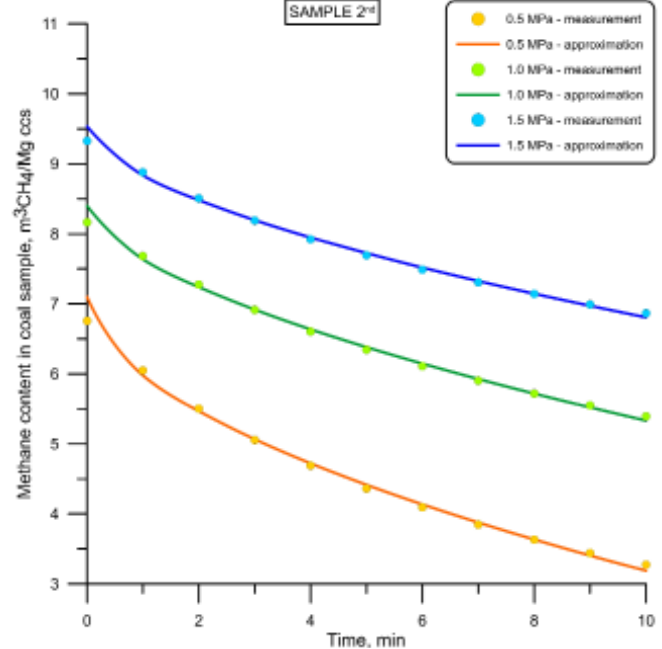

Fig. 3. Desorption curves (sample 2)

An analysis of all obtained desorption curves resulted in determining the degree of gas loss occurring when a sample of coal is collected for tests (Szlązak et al., 2011; Korzec, 2013). For the studies in question, the obtained value was 12 per cent, which was accepted as binding in the methodology under analysis.

\section{The procedure of determining coalbed methane content}

In order to determine the methane-bearing capacity of a coalbed, the following values have to be calculated in the order presented below:

- clear carbon substance content in the sample $z_{c c s}$ :

$$
z_{c c s}=100-\left(W_{m}+A_{a}\right), \quad \%
$$

where

$$
\begin{gathered}
W_{m}-\text { total moisture content in } \%, \\
A_{a}-\text { ash content in coal in } \%,
\end{gathered}
$$

- the mass of clear carbon substance $m_{c c s}$ :

$$
m_{c c s}=\frac{m_{c} \cdot z_{c c s}}{100}, \mathrm{~g}
$$

where

$m_{c}$ - the mass of coal sample in $\mathrm{g}$,

$z_{c c s}$ - clear carbon substance content in the sample in $\%$, 
- the volume of coal sample $V_{c}$ :

$$
V_{c}=\frac{m_{c}}{d_{c}}, \mathrm{~cm}^{3}
$$

where

$$
d_{c} \text { - coal density in } \mathrm{g} / \mathrm{cm}^{3},
$$

- the volume of remaining space in the steel container with the coal sample $V_{r s}$ :

$$
V_{r s}=V_{s}-\left(V_{c}+V_{b}\right), \mathrm{cm}^{3}
$$

where

$V_{s}$ - the capacity of the steel container with the coal sample in $\mathrm{cm}^{3}$,

$V_{c}$ - the volume of the coal sample in $\mathrm{cm}^{3}$,

$V_{b}$ - the volume of balls in the steel container with the coal sample in $\mathrm{cm}^{3}$,

- the volume of the gas mixture collected to the steel container during the sampling of coal with reference to the conditions in the place of sampling $V_{r S}^{\prime}$ (temperature of $20^{\circ} \mathrm{C}$ and air pressure of $1013.25 \mathrm{hPa}$ ):

$$
V_{r s}^{\prime}=0.2893 \cdot \frac{V_{r s} \cdot p_{e}}{273.15+t_{e}}, \mathrm{~cm}^{3}
$$

where

$p_{e}-$ atmospheric pressure in the excavation in $\mathrm{hPa}$,

$t_{e}-$ air temperature in the excavation in ${ }^{\circ} \mathrm{C}$,

- the volume of the gas mixture obtained by degasifying the sample $V_{o}$ with reference to the conditions in the place of degasification (temperature of $20^{\circ} \mathrm{C}$ and air pressure of $1013.25 \mathrm{hPa}$, and after the temperature in the measuring tank had become equal to the temperature in the laboratory):

$$
V_{o}=0.2893 \cdot \frac{V_{m} \cdot p_{m}}{273.15+t_{l}}, \mathrm{~cm}^{3}
$$

where

$V_{m}$ - the volume of the measuring container in $\mathrm{cm}^{3}$,

$p_{m}$ - the pressure of the gas mixture obtained by degasifying the sample in the measuring tank in $\mathrm{hPa}$,

$t_{l}$ - temperature of air in the laboratory in ${ }^{\circ} \mathrm{C}$,

- the volume of methane in the gas mixture obtained by degasifying the sample $V_{\mathrm{CH}_{4}}$ :

$$
V_{\mathrm{CH}_{4}}=\frac{V_{o} \cdot s_{\mathrm{CH}_{4}}}{100}, \mathrm{~cm}^{3}
$$

where

$V_{o}$ — the volume of the gas mixture obtained by degasifying the sample with reference to the conditions in the place of degasification in $\mathrm{cm}^{3}$,

$s_{\mathrm{CH}_{4}}$ - methane concentration in the gas mixture obtained by degasifying the sample in \%, 
- the volume of methane in the gas mixture obtained by degasifying the sample $V_{\mathrm{CH}_{4}}^{\prime}$ :

$$
V_{\mathrm{CH}_{4}}^{\prime}=\frac{V_{r s}^{\prime} \cdot c_{\mathrm{CH}_{4}}}{100}, \mathrm{~cm}^{3}
$$

where

$c_{\mathrm{CH} 4}-$ methane concentration in the excavation in $\%$,

- the volume of methane obtained from the coal sample $V^{\prime \prime}{ }_{\mathrm{CH}_{4}}$ :

$$
V_{\mathrm{CH}_{4}}^{\prime \prime}=V_{\mathrm{CH}_{4}}-V_{\mathrm{CH}_{4}}^{\prime}, \mathrm{cm}^{3}
$$

- methane content in the coal sample $M_{L}$ :

$$
M_{L}=\frac{V_{\mathrm{CH}_{4}}^{\prime \prime}}{m_{c c s}}, \mathrm{~m}^{3} \mathrm{CH}_{4} / \mathrm{Mgccs}
$$

The determined methane content $M$ of the coalbed, including the gas loss during sampling coal, is calculated from the following formula:

$$
M=1.12 \cdot M_{L}, \quad \mathrm{~m}^{3} \mathrm{CH}_{4} / \mathrm{Mg} \mathrm{ccs}
$$

\section{Evaluation of measurement uncertainty}

The method for calculating measurement uncertainty depends on how the final result is obtained. In this respect, measurements can be classified as direct and indirect.

According to the guide issued by the Central Office of Measures (ISO/UEC, 2008; GUM, 1999), the measurement uncertainty of indirect measurements is to be adopted as the standard uncertainty. Depending on the method of measurement, two types of standard uncertainty are distinguished: A and B. The method for calculating measurement uncertainty of type A is employed when it is possible to conduct a large number of independent measurements of a given value under the same conditions. These prerequisites need to be fulfilled because the method is based on the statistical analysis of the measured results. The method for calculating measurement uncertainty of type B is used when only one measurement was conducted or when the measured results do not show variation. In such a situation, measurement uncertainty is evaluated on the basis of all available information about a given property and about the range of values permitted for this property.

The uncertainty of indirect measurements is to be defined as a complex standard uncertainty and extended uncertainty. In the analysis presented below, the calculations were made for the standard uncertainty. In practice, apart from the methods outlined in the guide issued by the Central Office of Measures, there is also another method used to calculate maximal uncertainty (or maximal error).

The assumptions presented below were adopted for further analysis. The value $y$ to be determined is calculated from the following formula:

$$
y=f\left(x_{1}, x_{2}, \ldots, x_{k}\right)
$$

where:

$$
x_{1}, x_{2}, \ldots, x_{k}-\text { values measured indirectly, } j=1, \ldots, k .
$$


The complex standard uncertainty $u_{c}(y)$ of the measurement of a value calculated indirectly on the basis of values measured directly is determined by applying the principle of transferring the uncertainties of uncorrelated direct measurements using the following formula:

$$
u_{c}(y)=\sqrt{\sum_{j=1}^{k}\left(\frac{\partial f}{\partial x_{j}}\right)^{2} \cdot u^{2}\left(x_{j}\right)}
$$

In order to calculate the maximal uncertainty, the principle of transferring maximal uncertainty is applied. In the calculations, the values of the particular input variables are calculated in the same way as in the case of complex standard uncertainty, except that instead of a vector sum an algebraic sum of their absolute values is calculated from the following formula:

$$
\Delta y=\sum_{j=1}^{k}\left|\frac{\partial f}{\partial x_{j}} \cdot \Delta x_{j}\right|
$$

\section{Analysis of measurement uncertainty of coalbed methane content}

For the methodology designed to determine coalbed methane content which is presented in publications (Szlązak et al., 2011; Korzec, 2013) calculations of measurement uncertainty were conducted.

An analysis of the laboratory procedure for determining methane content in a coalbed shows that its value depends on 13 parametres obtained in the lab. The final formula used to determine methane content in a coal sample is as follows (symbols and units of each parameter are listed in Table 1):

$$
M_{L}=0.002893 \cdot \frac{\frac{V_{m} \cdot p_{m} \cdot s_{\mathrm{CH}_{4}}}{273.15+t_{l}}-\frac{\left(V_{s}-\frac{m_{c}}{d_{c}}-V_{b}\right) \cdot p_{e} \cdot c_{\mathrm{CH}_{4}}}{273.15+t_{e}}}{m_{c}-0.01 \cdot m_{c} \cdot\left(W_{m}+A_{a}\right)}, \mathrm{m}^{3} \mathrm{CH}_{4} / \mathrm{Mg} \mathrm{ccs}
$$

Formula (6.1) contains all parametres necessary to determine methane content in a coal sample. All the parametres along with their values of measurement uncertainty are listed in Table 1. The analysis of errors made while measuring particular parametres showed that absolute uncertainty should be assumed for such parametres as the volume of measuring tank, the volume of the airtight steel container, coal density, the volume of steel balls in an airtight steel container, atmospheric pressure and methane concentration in the excavation (where the sample was collected), air temperature (where the sample was collected and in the laboratory). However, for such parametres as gas pressure in the measuring tank, concentration of methane in gas mixture after degasification, coal sample mass, moisture content and ash content the value of relative uncertainty should be assumed. 
Parameters used to determine methane content in coal sample including their measuring uncertainty

\begin{tabular}{|l|c|c|c|c|}
\hline \multicolumn{1}{|c|}{ Parameter } & Symbol & Unit & $\begin{array}{c}\text { Absolute } \\
\text { uncertainty }\end{array}$ & $\begin{array}{c}\text { Relative } \\
\text { uncertainty }\end{array}$ \\
\hline volume of measuring tank & $V_{m}$ & $\mathrm{~cm}^{3}$ & 10.00 & - \\
\hline gas pressure in measuring tank & $p_{m}$ & $\mathrm{hPa}$ & - & $1.00 \%$ \\
\hline $\begin{array}{l}\text { concentration of methane in gas mixture } \\
\text { after degasification }\end{array}$ & $s_{\mathrm{CH}_{4}}$ & $\%$ & - & $3.0 \%-0.5 \% *$ \\
\hline volume of airtight, steel canister & $V_{s}$ & $\mathrm{~cm}^{3}$ & 10.00 & - \\
\hline coal sample mass & $m_{c}$ & $\mathrm{~g}$ & - & $1.00 \%$ \\
\hline coal density & $d_{c}$ & $\mathrm{~g}^{3} \mathrm{~cm}^{3}$ & 0.02 & - \\
\hline $\begin{array}{l}\text { volume of steel balls in airtight, } \\
\text { steel canister }\end{array}$ & $V_{b}$ & $\mathrm{~cm}^{3}$ & 1.00 & - \\
\hline $\begin{array}{l}\text { atmospheric pressure in an excavation } \\
\text { (where the sample was collected) }\end{array}$ & $p_{e}$ & $\mathrm{hPa}$ & 1.00 & - \\
\hline $\begin{array}{l}\text { methane concentration in the excavation } \\
\text { (where the sample was collected) }\end{array}$ & $c_{\mathrm{CH}_{4}}$ & $\%$ & 0.05 & - \\
\hline temperature in the laboratory & $t_{l}$ & ${ }^{\circ} \mathrm{C}$ & 0.20 & - \\
\hline $\begin{array}{l}\text { temperature in the excavation } \\
\text { (where the sample was collected) }\end{array}$ & $t_{e}$ & ${ }^{\circ} \mathrm{C}$ & 0.20 & - \\
\hline moisture content & $W_{m}$ & $\%$ & - & $1.00 \%$ \\
\hline ash content & $A_{a}$ & $\%$ & - & $3.00 \%$ \\
\hline
\end{tabular}

* depending on methane concentration in the mixture

The analysis of measurement uncertainty was conducted for 78 measurements of methane content in coal.

At the beginning, partial derivatives of $M_{L}$ methane in a coal sample with respect to particular parametres (which are a part of dependence 6.1) presented in Table 2 were calculated. These partial derivatives are also called sensitivity coefficient.

Partial derivatives of $M_{L}$ with respect to the parameters used for its deetermination

\begin{tabular}{|l|c|}
\hline $\begin{array}{c}\text { Partial derivative of } \boldsymbol{M}_{\boldsymbol{L}} \\
\text { with respect to the variable }\end{array}$ & \multicolumn{1}{c|}{ 1 } \\
\hline \multicolumn{1}{|c|}{ vartial derivative } \\
\hline volume of measuring tank & $\frac{\partial M_{L}}{\partial V_{m}}=\frac{2}{\left(273.15+t_{l}\right) \cdot m_{c} \cdot\left(1-0.01 \cdot W_{m}-0.01 \cdot A_{a}\right)}$ \\
\hline $\begin{array}{l}\text { gas pressure } \\
\text { in the measuring tank }\end{array}$ & $\frac{\partial M_{L}}{\partial p_{m}}=\frac{0.002893 \cdot V_{m} \cdot s_{\mathrm{CH}_{4}}}{\left(273.15+t_{l}\right) \cdot m_{c} \cdot\left(1-0.01 \cdot W_{m}-0.01 \cdot A_{a}\right)}$ \\
\hline $\begin{array}{l}\text { concentration of methane } \\
\text { in gas mixture after } \\
\text { degasification }\end{array}$ & $\frac{\partial M_{L}}{\partial s_{\mathrm{CH}_{4}}}=\frac{0.002893 \cdot V_{m} \cdot p_{m}}{\left(273.15+t_{l}\right) \cdot m_{c} \cdot\left(1-0.01 \cdot W_{m}-0.01 \cdot A\right)}$ \\
\hline
\end{tabular}




\begin{tabular}{|c|c|}
\hline 1 & 2 \\
\hline $\begin{array}{l}\text { volume of airtight, steel } \\
\text { canister }\end{array}$ & $\frac{\partial M_{L}}{\partial V_{s}}=-\frac{0.002893 \cdot p_{e} \cdot c_{\mathrm{CH}_{4}}}{\left(273.15+t_{e}\right) \cdot m_{c} \cdot\left(1-0.01 \cdot W_{m}-0.01 \cdot A_{a}\right)}$ \\
\hline coal sample mass & $\begin{aligned} \frac{\partial M_{L}}{\partial m_{c}}= & -\frac{0.002893 \cdot V_{m} \cdot p_{m} \cdot s_{\mathrm{CH}_{4}}}{\left(273.15+t_{l}\right) \cdot m_{c}^{2} \cdot\left(1-0.01 \cdot W_{m}-0.01 \cdot A_{a}\right)} 1+ \\
& +\frac{0.002893 \cdot p_{e} \cdot c_{\mathrm{CH}_{4}} \cdot V_{s}}{\left(273.15+t_{e}\right) \cdot m_{c}{ }^{2} \cdot\left(1-0.01 \cdot W_{m}-0.01 \cdot A_{a}\right)}- \\
& \frac{0.002893 \cdot p_{e} \cdot c_{\mathrm{CH}_{4}} \cdot V_{b}}{\left(273.15+t_{e}\right) \cdot m_{c}{ }^{2} \cdot\left(1-0.01 \cdot W_{m}-0.01 \cdot A_{a}\right)}\end{aligned}$ \\
\hline coal density & $\frac{\partial M_{L}}{\partial d_{c}}=-\frac{0.002893 \cdot p_{e} \cdot c_{\mathrm{CH}_{4}}}{\left(273.15+t_{e}\right) \cdot\left(1-0.01 \cdot W_{m}-0.01 \cdot A_{a}\right) \cdot d_{c}^{2}}$ \\
\hline $\begin{array}{l}\text { volume of steel balls in the } \\
\text { airtight, steel canister }\end{array}$ & $\frac{\partial M_{L}}{\partial V_{b}}=\frac{0.002893 \cdot p_{e} \cdot c_{\mathrm{CH}_{4}}}{\left(273.15+t_{e}\right) \cdot m_{c} \cdot\left(1-0.01 \cdot W_{m}-0.01 \cdot A_{a}\right)}$ \\
\hline $\begin{array}{l}\text { atmospheric pressure in } \\
\text { the excavation (where the } \\
\text { sample was collected) }\end{array}$ & $\frac{\partial M_{L}}{\partial p_{e}}=-\frac{0.002893 \cdot c_{\mathrm{CH}_{4}} \cdot\left(V_{s}-\frac{m_{c}}{d_{c}}-V_{b}\right)}{\left(273.15+t_{e}\right) \cdot m_{c} \cdot\left(1-0.01 \cdot W_{m}-0.01 \cdot A_{a}\right)}$ \\
\hline $\begin{array}{l}\text { methane concentration in } \\
\text { the excavation (where the } \\
\text { sample was collected) }\end{array}$ & $\frac{\partial M_{L}}{\partial c_{\mathrm{CH}_{4}}}=-\frac{0.002893 \cdot p_{e} \cdot\left(V_{s}-\frac{m_{c}}{d_{c}}-V_{b}\right)}{\left(273.15+t_{e}\right) \cdot m_{c} \cdot\left(1-0.01 \cdot W_{m}-0.01 \cdot A_{a}\right)}$ \\
\hline $\begin{array}{l}\text { temperature in the } \\
\text { laboratory }\end{array}$ & $\frac{\partial M_{L}}{\partial t_{l}}=-\frac{0.002893 \cdot V_{m} \cdot p_{m} \cdot s_{\mathrm{CH}_{4}}}{\left(273.15+t_{l}\right)^{2} \cdot m_{c} \cdot\left(1-0.01 \cdot W_{m}-0.01 \cdot A_{a}\right)}$ \\
\hline $\begin{array}{l}\text { temperature in the } \\
\text { excavation (where the } \\
\text { sample was collected) }\end{array}$ & $\frac{\partial M_{L}}{\partial t_{e}}=\frac{0.002893 \cdot p_{e} \cdot c_{\mathrm{CH}_{4}} \cdot\left(V_{s}-\frac{m_{c}}{d_{c}}-V_{b}\right)}{\left(273.15+t_{e}\right)^{2} \cdot m_{c} \cdot\left(1-0.01 \cdot W_{m}-0.01 \cdot A_{a}\right)}$ \\
\hline moisture content & $\begin{aligned} \frac{\partial M_{L}}{\partial W_{m}}= & \frac{0.00002893 \cdot V_{m} \cdot p_{m} \cdot s_{\mathrm{CH}_{4}}}{\left(273.15+t_{l}\right) \cdot m_{c} \cdot\left(1-0.01 \cdot W_{m}-0.01 \cdot A_{a}\right)^{2}}- \\
& \frac{0.00002893 \cdot p_{e} \cdot c_{\mathrm{CH}_{4}} \cdot\left(V_{s}-\frac{m_{c}}{d_{c}}-V_{b}\right)}{\left(273.15+t_{e}\right) \cdot m_{c} \cdot\left(1-0.01 \cdot W_{m}-0.01 \cdot A_{a}\right)^{2}}\end{aligned}$ \\
\hline
\end{tabular}




\begin{tabular}{|c|c|}
\hline 1 & $\mathbf{2}$ \\
\hline ash content & $\frac{\partial M_{L}}{\partial A_{a}}=\frac{0.00002893 \cdot V_{m} \cdot p_{m} \cdot s_{\mathrm{CH}_{4}}}{\left(273.15+t_{l}\right) \cdot m_{c} \cdot\left(1-0.01 \cdot W_{m}-0.01 \cdot A_{a}\right)^{2}}-$ \\
& $\frac{0.00002893 \cdot p_{e} \cdot c_{\mathrm{CH}_{4}} \cdot\left(V_{s}-\frac{m_{c}}{d_{c}}-V_{b}\right)}{\left(273.15+t_{e}\right) \cdot m_{c} \cdot\left(1-0.01 \cdot W_{m}-0.01 \cdot A_{a}\right)^{2}}$ \\
\hline
\end{tabular}

Standard uncertainty was determined from the formula (5.2). The determined measurement uncertainty was referred to the value of determined methane content in a coal sample and presented as relative uncertainty. The same calculations were conducted for maximum uncertainty from the formula (5.3).

The relationship between the standard relative uncertainty of determining methane content in a coal sample and the value of methane content in a coal sample is presented in Figure 4. The relationship between the maximum relative uncertainty of determining methane content in a coal sample and the value of methane content in a coal sample is presented in Figure 5.

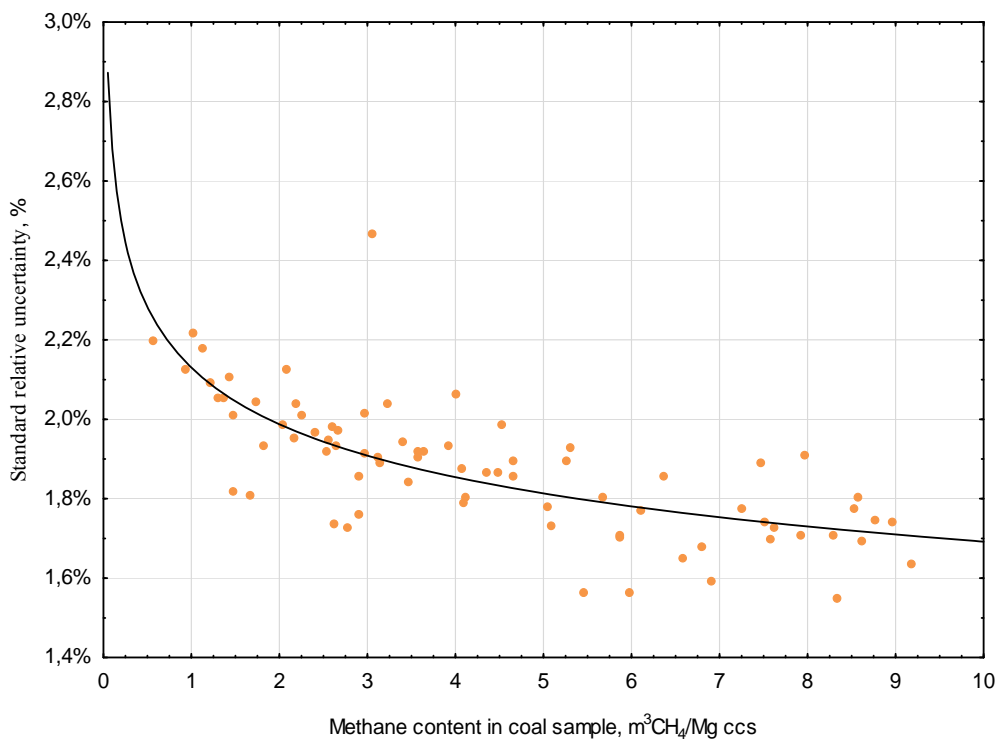

Fig. 4. Relationship between standard relative uncertainty of determining methane content in coal sample and the value of methane content in coal sample

For each sample analyzed with respect to determining measurement uncertainty of coal samples, extra calculations of the contribution of particular parametres to combined uncertainty were conducted. Those calculations showed that only six out of 13 parametres used for determining methane content in a coal sample have a significant influence on the result. Average percentage contributions to uncertainty are listed in Table 3. 


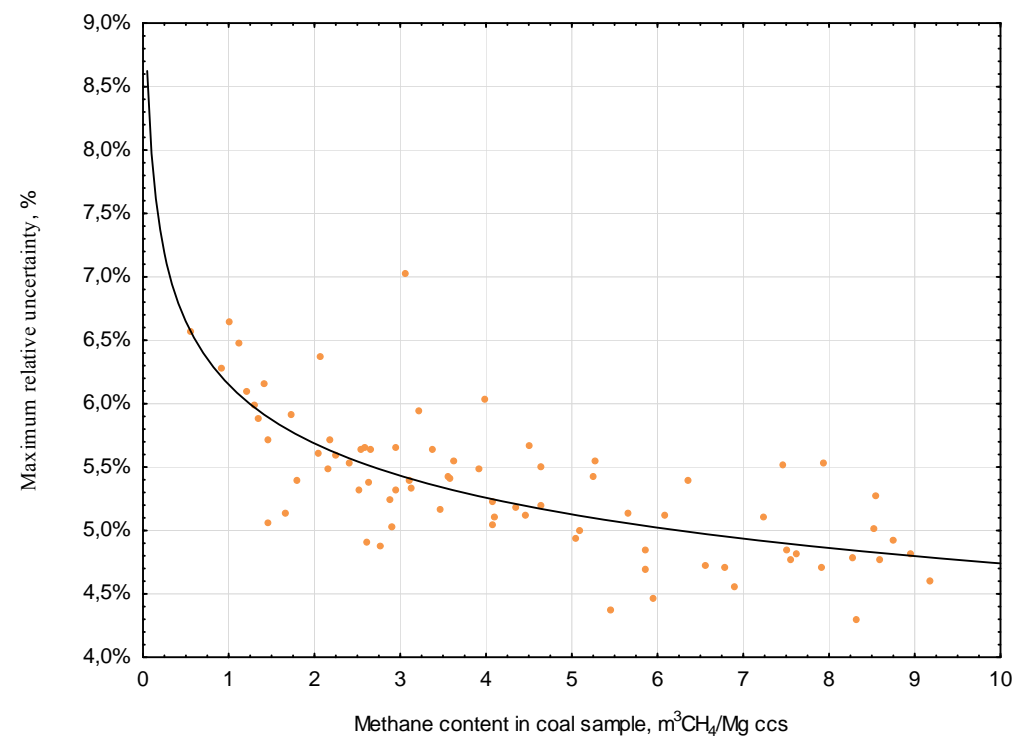

Fig. 5. Relationship between maximum relative uncertainty of determining methane content in coal sample and the value of methane content in coal sample

Contributions of the measured parametres to uncertainty in relation to uncertainty of determined values of methane content in a coal sample

\begin{tabular}{|l|c|c|c|}
\hline \multicolumn{1}{|c|}{ Parameter } & Symbol & Unit & $\begin{array}{c}\text { Percentage uncertainty } \\
\text { participation }\end{array}$ \\
\hline volume of measuring tank & $V_{m}$ & $\mathrm{~cm}^{3}$ & $5.70 \%$ \\
\hline gas pressure in the measuring tank & $p_{m}$ & $\mathrm{hPa}$ & $9.70 \%$ \\
\hline $\begin{array}{l}\text { concentration of methane in the mixture after } \\
\text { degasification }\end{array}$ & $s_{\mathrm{CH}_{4}}$ & $\%$ & $51.50 \%$ \\
\hline coal sample mass & $m_{c}$ & $\mathrm{~g}$ & $28.70 \%$ \\
\hline $\begin{array}{l}\text { methane concentration in the excavation } \\
\text { (where the sample was collected) }\end{array}$ & $c_{\mathrm{CH}_{4}}$ & $\%$ & $1.30 \%$ \\
\hline ash content & $A_{a}$ & $\%$ & $3.10 \%$ \\
\hline
\end{tabular}

\section{Conclusions}

Determining the coalbed methane content can be carried out in accordance with the method presented in the article, which unify the methods used until now.

The conducted analysis of measurement uncertainty shows that the methodology for determining methane content in a coal sample is sufficiently accurate. Relative measurement uncertainty for each sample did not exceed 2.5 per cent, while maximum relative uncertainty did not exceed 7.0 per cent. The graphs presented in Figures 4 and 5 show that measurement uncertainty was higher for the lower values of methane content in a coal sample. 
During analysis, the contributions of the measured parametres to percentage uncertainty in relation to the uncertainty of the determined value of methane content in a coal sample were established. The average values of this participation show that the accuracy of determining such parametres as methane concentration in the mixture after degasification, coal sample mass, gas pressure in the measuring tank, the volume of the measuring tank, ash content and methane concentration in the excavation (where the sample was collected) have the greatest influence on the value of methane content in a coal sample. The method for determining other parametres is accurate enough and has no significant impact on determining methane content in a coal sample.

This work was supported by the National Centre for Research and Development - Project No. NR09002106

\section{References}

Arendarski J., 2006. Niepewność pomiarów. Oficyna Wydawnicza Politechniki Warszawskiej (in Polish).

Branny M., 2006. Computer simulation of flow of air and methane mixture in the longwall-return crossing zone. Archives of Mining Sciences, Vol. 51, No 1, p. 133-145.

Giercuszkiewicz-Bajtlik M., Gworek B., 2009. Metody wyrażania niepewności pomiaru w analizie chemicznej próbek środowiskowych. Ochrona Środowiska i Zasobów Naturalnych, nr 39, p. 133-148 (in Polish).

Główny Urząd Miar, 2009. Wyrażanie niepewności pomiaru. Przewodnik GUM, Warszawa (in Polish).

International Standard Organization, 2008. ISO/IEC Guide 98-3:2008 Uncertainty of measurement - Part 3: Guide to the expression of uncertainty in measurement. Switzerland.

Korzec M., 2013. Opracowanie metody oznaczania metanonośności w poktadach węgla kamiennego. Rozprawa doktorska, Akademia Górniczo-Hutnicza im. Stanisława Staszica w Krakowie (in Polish).

Polski Komitet Normalizacyjny, 2013. PN-G-44200 - Górnictwo - Oznaczanie metanonośności w pokładach węgla kamiennego - Metoda zwiercinowa (in Polish).

Projekt rozwojowy NCBiR nr NR09002106, 2009-2010. Opracowanie metody oznaczania zawartości metanu (metanonośności) w pokładach węgla kamiennego. Realizowany w Akademii Górniczo-Hutniczej w Krakowie, Wydział Górnictwa i Geoinżynierii w latach 2009-2010 (in Polish).

Rozporządzenie Ministra Gospodarki z dnia 28 czerwca 2002 r. w sprawie bezpieczeństwa i higieny pracy, prowadzenia ruchu oraz specjalistycznego zabezpieczenia przeciwpożarowego w podziemnych zakładach górniczych (Dz. U. Nr 139, poz. 1169 wraz z późniejszymi zmianami) (in Polish).

Szlązak N., Borowski M., Obracaj D., Swolkień J., Korzec M., 2011. Metoda oznaczania metanonośności w pokładach węgla kamiennego. Wydawnictwa AGH, Kraków (in Polish).

Szlązak N., Kubaczka Cz., 2012. Impact of coal output concentration on methane emission to longwall faces. Archives of Mining Sciences, Vol. 57, No 1, p. 3-21.

Taylor R. J., 1999. Wstęp do analizy błędu pomiarowego. Wydawnictwo Naukowe PWN, Warszawa (in Polish).

Terenowski H., 2010. Szacowanie niepewności pomiarów. Problemy Techniki Uzbrojenia, z. 115, nr 8/2010, s. 77-84, Zielonka (in Polish).

Wierzbicki M., 2013. The effect of temperature on the sorption propertiess of coal from Upper Silesian Coal Basin, Poland. Archives of Mining Sciences, Vol. 58, No 4, p. 1163-1176. 